\title{
Definition issues of concepts of social cleavages in Africa
} https://dx.doi.org/10.4314/rj.v2i2.3A

\author{
Dr. Nkaka Raphael, Senior Lecturer \\ College of Arts and Social Sciences \\ School of Journalism and Communication \\ University of Rwanda
}

\begin{abstract}
This paper is about the definition issues of the social cleavage concepts with a focus on Africa. Social scientists have introduced into their field of research concepts that express social cleavages, favoring the concepts such as "race", "ethnic", "tribe", "caste" or "social class". The main problem is whether the definitions of concepts are coherent to reflect the complex social realities. Based on the theoretical framework and on the analysis of the definitions, it becomes clear that the social cleavage concepts are not consistent once applied to African societies. For the Rwandan society in particular, it is interesting to realize that a distinguished scholar has never adopted the same concept to identify Hutu, Tutsi and Twa in his works with long-time career. For future researches, it would be better to conduct field surveys before defining a social cleavage concept while taking in account the society dynamic.
\end{abstract}

Key words: race, ethnic, caste, cleavage, Africa, Rwanda

\section{INTRODUCTION}

This study aims to examine the definitions of concepts related to social cleavages in order to evaluate the relevance of the latter when applied to African societies. The main problem is whether those definitions are sufficiently clear and coherent to reflect the complex social realities of this region of the world. To solve this problem, I intend to use the theoretical framework fostered by definitions of concepts given by different authors as well as an analysis of those definitions once applied to the envisaged social cleavages. The results followed by a conclusion will be proposed.

\section{THEORETICAL CONTEXT OF THE STUDY}

This work focuses on the definitions of those concepts given by authors, then it examines the cases where those concepts have been applied. This will make it possible to assert whether those concepts have been clearly applied consistently to those various cases. This approach will then allow me to verify whether those concepts, once applied to 
African societies, with a particular emphasis on Rwandan society, will remain coherent. A discussion of the findings may reflect the relevance or lack of validity of those concepts to identify the social divides.

\section{FINDINGS}

Social scientists have introduced into their fields of research concepts that express social cleavages. They have favored the use of concepts such as "race", "ethnic", "tribe", "caste" or "social class" in the analysis of those cleavages. To account for how they have privileged those uses, I will discuss how they have approached those concepts by defining them and providing them with a theoretical framework.

Delacampagne (1983: 35) recalled that the word "race" appeared in French vocabulary in the 16th century, borrowed from the Italian razza which means "sort, species", which derives from the Latin ratio "reason" meaning "order of things, category, species "and that it was in the Middle Ages that a shift of meaning would have occurred from "category, species" to "lineage". That term, previously applied to animal varieties domesticated by man, was applied to human beings from the sixteenth century onwards. It was between the end of the eighteenth century and the beginning of the twentieth that the concept of "race" entered into the lexical formation of an ideology intended to explain social inequalities and the merits of colonization. The race then became an intellectual category, but pseudo-scientific. Thus there was crystallization of what is known as racial ideology or racial doctrines. Simar (2003) presented the latter meanings to support the idea that ethnic groups were irreducible to each other, that they should continue their historical evolution as part of their own genius, that they were, by their very nature, either predestined for progress or for eternal inferiority, and that this greatness or unworthiness was imposed on them by physico-physiological characteristics.

Clearly, there is a necessary link between biological characteristics and social behaviors. This theory is based on an essentialist view of the idea of race. According to this approach, men or cultures are eternally immutable. This way of thinking is opposed to a historicizing approach that takes into account the fact that people change over time and depending on their social living conditions (Memmi, 1994).

For Guillaumin (2002), that ideology was forged in a particular context in the history of Western Europe. In the wake of the development of the natural sciences outside theology, the origin and filiation became the axes of scientific thought, a change incarnated by darwinism and the birth of evolutionism between 1850 and 1860. Fredrikson (2003) tried to explain the context of its flowering by the rejection by the European powers of egalitarian norms introduced by the French Revolution and that of colonial imperialism from 1870, since that ideology justified the political and strategic ambitions of the 
colonial powers. It was then in the 1930s that the concept of "racism" appeared, the peculiarity of which was the absolute differentiation of the "races" and the hostility towards a "racial group". Memmi gave a definition that includes that peculiarity: "Racism is the widespread and definitive valorization of real or imaginary differences for the benefit of the accuser and to the detriment of his victim, in order to justify aggression or privilege" (1994: 193). The term "racism" is thus posterior to racial theories and contains an intention of aggression or exploitation which racial theories did not necessarily involve. Its appearance in the 1930s is not unrelated to the rise of Nazism. That calls for other expressions related to the concept of "race", such as "raciology" or "racialization". The term "raciology" refers to the study of those doctrines, while the latter refers to the transformation of social groups into racial units or the polarization of events on the racial. From there, I am a touching upon the expression "racial logic". The latter may mean a coherent reasoning which leads to a perception of facts and events according to a racial vision by eliminating varied situations and dynamics of social, political and economic transformations. The last two concepts indicate that the situations to which they refer do not correspond to a racial classification but rather express the intention of the actors to interpret them in racial terminology.

Since it was not easy to objectively identify racial indices, anthropologists established measurement techniques to give a scientific coloration to their racial theories. Anthropometry was born and served as a technique for physical classifications based on considerations such as the shape of the skull, the shape of the nose and hair, and the size of individuals. The principal measurements of the skull were the volume of the brain, the facial angle, and the cephalic index. Concerning the facial angle, the salient character of the face and the jaws was considered a sign of "racial" inferiority. The notions of brachycephaly, dolichocephaly, and mesocephaly were used to measure the cephalic index, that is, the ratio between the maximum width and length of a skull. De Fontette (1985) introduced us into physical anthropology by establishing the following typology: when this ratio was less than 0.75 , the subject was said to be dolichocephalic; it was said to be brachycephalic, if the ratio was greater than 0.80 and mesocephalic, when the ratio was between 0.75 and 0.80 . If, for the size, we take as the basis, the approximate average of masculine humanity of $1.65 \mathrm{~m}$, the high sizes will be situated above $1.70 \mathrm{~m}$ and the low ones below $1.60 \mathrm{~m}$ while sizes smaller than $1.50 \mathrm{~m}$ are characteristic of some "races" known as "pygmies". When the hair is straight with a circular section, it is typical of the yellow faces; it is more flexible and found in Europe; when frizzy and wrapped in very tight turns on the head, it is typical to the black faces. This typology was based on the postulate of the division of humanity into three human races differentiated by the color of the skin: white, yellow and black. 
"Mendel laws" on the hereditary transmission of phenotypic characters in 1865 and the discovery of the blood system ABO in 1900 by Landsteiner revived the debate. Lainé (1999) found that the blood groups constituted isolated factors whose heredity mechanisms were known, and that the evolution of those traits could then be studied in populations using parameters such as size, endogamy degree, or selection factors. She noted in addition that the notion of "race" was concerned with population genetics, since anthropology sought to reassure itself that judicious "racial" classifications would make it possible to specify the prehistory of modern populations and the pattern of a separate evolution of "races" in the long run. Ducros (1992), for his part, believes that in the eyes of some researchers like Boyd, the notion of "race" was not as difficult and embarrassing as it was for anthropologists. In his view, "race is only a constellation of characters" and "a race can be defined as a population that differs significantly from other human populations by the frequency of one or more genes it has."

Given that racial ideology is a set of scientific theories, and given the problems associated with the definitions of the concept of "race", one may well ask about the relevance of that ideology and even that of the concept of "race" as an object of study. Poutignat and Streiff-Fenart (2008, 43) suggested that, in its contemporary sense, the term "race" no longer denotes "bio-somatic heredity" but the perception of physical differences in that they have an impact on the status of groups and social relations. Therefore, for Banton (1967), the word "race" applies to both physical and social classifications, while specifying that those classifications, although overlapping, can never be identical. He admitted that the theory of races in separate and distinct groups is completely discredited, but argued that those theories must be studied, since social relations have been influenced over the last two hundred years by what has been believed being the nature of the race. Then, true or false opinions about the character of the race have always a great social significance, and when one class is designated according to racial terminology, one can predict some of the consequences that will follow. So it is not race, as such, also noted Poutignat and Streiff-Fenart (2008), but racial relationships that constitute an object for sociology.

Concerning the definitions of "ethnic" concept, Boilley (2003: 11-12) noted that the term "ethnic" is a euphemism for the word "tribe" and has retained its pejorative meaning. As regards the term "ethnicity" he considers that it is polysemic: "Ethnic group is first of all the others, those who are less civilized (developed, organized, state-controlled, etc.) than those who take it upon to categorize them in this way: barbarians (Ethnos of the Greeks organized in city-states), pagans (ethnicus of Latin ecclesiastics), blacks, latinos (ethnicities of the white Yankees of Anglo-Saxon sociology in the 1940s ), Africans (ethnicities of colonial anthropologists), etc. 
With the concept of "ethnic" has been associated the term "ethnicity". Given the link between the concepts of "ethnic" and "ethnicity", it is necessary to consider them together through the content of research in social sciences. According to Poutignat and StreiffFenart (2008), the enormous literature on ethnicity should not be misleading, for in the majority of cases the term ethnicity is used as a descriptive category intended to deal with a sociopolitical problem rather than a sociological concept for defining a scientific object. He added that in the 65 definitions reviewed by Isajiw, most have no explicit definition. Rather, he suggested that the notion of "ethnicity" largely consists not of certifying the existence of ethnic groups, but of considering that existence as being problematic, that is, of regarding as problematic the consubstantiality of a social entity and of a culture whereby the ethnic group is usually defined.

Guillaumin (2002) considered the terms "ethnicity" and "race" to have the same meanings, although the former avoids the discomfort caused by the concept of "race". Confusion between ethnic groups and racial groups was justified by Weber (1995). He defined "racial belonging " as having dispositions which are similar and transmitted by heredity, which is really based on the community of origin. However, that sense of belonging leads to "a community" only if it is subjectively felt as a common characteristic. That implies that having hereditary dispositions is not sufficient to create a racial belonging, but that it is necessary to be conscious of forming a racial group. The latter includes an essential element which is common to ethnic groups, insofar as Weber defined them as human groups which nourish a subjective belief in a community of origin based on similarities of the external habitus or customs, or both, or on memories of colonization or migration, so that this belief becomes important for the propagation of communalization, regardless of whether a community of blood exists objectively or not. It is, in Weber's mind, the subjective belief in forming a group that leads to the same reality a "racial group" and an "ethnic group."

Let us now deal with the notions of caste and social class. Bougle (1969) identified the main elements of the definition of "caste". This concept first awakens the idea of hereditary specialization. Thus the blacksmith's son will be a blacksmith and the warrior's son, a warrior; no one other than the son can continue the profession of his father. The word "caste" also refers to works that are hereditarily divided and rights unequally distributed, since who says "caste" says monopoly and privilege. By virtue of his/her birth, one individual pays heavy taxes, another is exempted from them. Moreover, the different groups reject each other and marriages between members of those groups are prohibited. In short, their personal status is determined, for life, by the rank of the group to which they belong. Banton (1967) referred to the religious character of those differentiations, since the hierarchy corresponds to a religious situation and political 
power depends on religious virtue. This means that those differentiated characteristics are based on a common principle: the opposition between the pure and the impure in all domains, so that the system consists of an opposition between the top and the bottom. Taguieff (1998) insisted that the hierarchy was not based on the "ethno-racial" principle, but acknowledged that, inspired by "ethno-racial" nationalism, a Hindu nationalism had emerged, equivalent to a racist ideology.

The caste system often refers to Indian society and examples of different relationships among castes are often drawn from that society. I also borrow the Indian case to illustrate such reports: "A Nayar must stand at a distance of seven feet from a Brahman Nambudiri, an Iravan at 32 feet, a Cheruman at 64 and a Nyadi must keep a respectful distance from 74 to124 feet. [...] When a Nyadi travels, he/she must avoid not only the people of other castes, but houses, pools, temples and even some rivers where one could bathe. ... The Nyadi must be careful not to cross the long bridge of the Ponnani River and must make long detours, for if they set foot on the bridge they would defile it or defile those who would come in contact with the traces of their footsteps (Banton 1971, 97).

Mousnier (1969) suggested that the opposition between purity and impurity governs the opposition between castes and social distance is materialized by physical distance. On the top of the hierarchy are the Brahmans castes, priests devoted to worship and education, come second the Kshatriyas castes, devoted to the profession of arms and the exercise of political and administrative power, are third the Vais'Yas caste, to agriculture and the lowest rank, the Sudras caste, in the service of all the others.

Mousnier (1969) estimated, moreover, that class society appears in a market economy when the supreme social value is placed in the production of material goods, when the supreme social esteem, honor, social dignity, go to the entrepreneur of such a production, when it is the role played in the mode of production of material goods and secondarily the money gained by this role which places individuals at various levels of social hierarchy.

\section{DISCUSSION}

When that hierarchy of human "races" was applied to Africa, it sometimes experienced contradictions challenging the relevance of racial theories. The classic book of Seligman (1966) offers an interesting case in this regard. On the one hand, he states that the Hamites belong to the races of Africa, and sets an equivalence between the Hamitic civilizations and the African civilizations, with the exception of the Semitic influences located in the north of the continent. On the other hand, he reveals that those Hamites are Europeans and contradicts himself by establishing equity between African civilizations and European civilizations. Bazin (1985) found contradictions in the racial descriptions of the Bambara in West Africa. Sometimes, he observes, they are described as "a 
conquering race" with all the features of savagery: "stupid, superstitious", "fatalistic beyond any idea," "sheep-robbers ", sometimes with the features of civilized "men:" affable, discreet, hospitable, polite, and complacent ". In addition, the identification of the Bambara was problematic in the midst of other identities such as the Kagoros or Masasi and each scientist described them in his/her own way. Delafosse proposed to "reserve the name of race to the great divisions of the human race" and considered it quite inappropriate to speak of a "Peul race" or a "Mandé race", "but pointed out that the designation Peul "or" Mandé "as an" ethnic group "has to do with a scholarly language in relation to the use of the name of " race ". (Bazin, 1985, 115)

Amselle (1985) emphasized the late emergence and specification of the terms "ethnic group" and "tribe" and attributed their massive use to the detriment of the concept of "nation" by the concern to classify some societies separately, especially African societies, by denying them their historicity. The synthesis of the definitions that he made reveals a number of common criteria such as language, space, customs, values, a name, the same descent and the awareness of social actors that they belong to the same group. He noted that these criteria are being challenged by Nadel, who has shown that the political and social organization of Nigeria's Nupes is common to many tribes in West Africa, but also by Meillassoux who wondered whether the Guru from Ivory Coast really exists as an "ethnic group", since, according to him, the only relevant social units seemed to him to be the matrimonial areas, while the consciousness of belonging to a single nation results from the political action of "the African Democratic Rally "

Other works have highlighted the role of colonial systems in the artificial creation of "tribes" / "ethnic groups". Dozon (1985) revealed that the notion of the " Bété country " of the current Ivory Coast has no real correspondent in the pre-colonial sphere and is the product of a colonial history during which administrative, economic and political factors have combined and produced the Bété ethnicity. M'bokolo (1985) recalled that Vansina had pointed out that many tribes did not exist before the colonial occupation which created them, notably by giving them a label. It is in that logic that Chrétien noted that ethnicity is the reference phantom, since ethnology has become the mold in which research had to flow.

In contrast, Schilder and Van Binsberger suggested that this vision confers an apparent passivity on African peoples and hides the historicity of some elements contributing to ethnic identity that have pre-colonial roots. According to them, the influence of the colonial State is exaggerated in the studies on the evolution of ethnicity to the detriment of the pre-colonial processes of formation of the groups (Fardon, 1996). Lonsdale (1996) noted, however, that some aspects of ethnicity do indeed represent a legacy of traditions, 
its meaning being reinvented every time to meet new needs. That is why, Fardon suggested, ethnicity is a historically moving category.

On the other hand, Barth introduced the notion of ethnic boundary to emphasize that ethnicity can only be determined in relation to a line of demarcation between members and non-members, and that it is in reality the ethnic boundaries, and not the internal cultural content, which define the ethnic group and make it possible to account for its persistence (Poutignat and Streiff-Fenar, 2008). Armstrong instead drew attention to the intellectual and subjective dimension of the ethnic group, noting that the mechanisms of ethnic boundaries exist in the heads of subjects rather than as lines on a map or as rules in a textbook (Poutignat and Streiff-Fenar, 2008). Experts should then take into account the opinions of those concerned before determining the "ethnic" boundaries, but this has not always been the case. In that regard, the "Ethnic Map of the Congo, Southeast Quarter"'established by M'bokolo is a striking example (M'bokolo, 1985)

From the point of view of population genetics, Laine noted the need to examine first the historical specificity of the populations to be studied and found that that fact has not always been respected. Moreover, she observed a chronological discrepancy between the constitution of the data and the time of the synthesis, since it is not easy in this case to verify the information considered.

The application of those concepts to Rwandan society to designate the Hutu, Tutsi and Twa identities was not consistent. The concept of "race" dominated the literature on Rwanda since the end of the nineteenth century until the 1970s when it was replaced by that of "ethnic group". Kagame $(1954,1972)$ embodied that situation. During the colonial era, he used the concept of "race" while the term "ethnic" was mostly used in the 1970s. And yet, those identities share common traits such as language, territory, customs and traditions. The same applies to the concept of "tribe" or "ethnic group". The first is found in the german writings of the late nineteenth and early twentieth century, but has not been used as widely as "race" or "ethnic ". The concept of "social class" was also used to designate those identities. De Lacger (1939) superimposed it on that of "race" in order to explain the contrast between the plurality of races and national sentiment. D'Hertefelt (1971) used it when he addressed the issue of the "multi-class" character of the Rwandan clans. He himself affirmed that he adopted this concept after realizing the ineffectiveness of the concept of "caste" and that he preferred to designate those identities as "endogamic and hierarchized classes". As for the concept of "caste", it is found particularly in Maquet (1952) when he asserts that at the beginning of the twentieth century, the two main castes were that of the Hutu farmers and the Tutsi pastors. Two years later, he justified the term "caste" applied to Rwanda by endogamy, economic specialization and the hierarchy of strictly separated hereditary groups (De Lacger, 1954). Ten years later, he abandoned the 
concept of "caste" in favor of that of "social class" (De Lacger, 1964). Other authors such as Vansina (1962), D'Hertefelt (1962) or De Heusch (1966) also used that concept. Later, D'Hertefelt (1971) will recognize that this concept is not appropriate and Vansina (2001, 53) will prefer that of "social category" or "social orders". Nyagahene (1997) challenged the concept of "social category" with the argument that members of each social group did not have the same attributes beyond the simple appellation and that there were no pure farmers or no pure cattle breeders. D'Hertefelt acknowledged later that the principal trouble came from the criterion of economic specialization. According to him, at the beginning of the twentieth century, a large number of Tutsi cultivated the land and the Hutu took care of the Tutsi cattle, as well as their own cows. In that way, he concluded, the notion of economic specialization dissolved. From that moment on, he rejected the use of "caste" in favor of that of "social class". On the other hand, Nyagahene did not feel comfortable with this new approach. His main argument is: "Specialization has always been unknown to really talk about social classes. If the majority of the great cattle breeders were among the Tutsi, there were also found among the Hutu and among the small peasants and simple farmers, there were also Tutsi and Hutu although the latter constituted the majority of them" (Nyagahene , 1997, 68)

Concerning population genetics, Desmarais (1978) argued that the Tutsi of pre-colonial Rwanda would have applied to themselves their breeding methods of which they applied to the cows until they succeeded in artificial selection before concluding that it was for that reason that the Tutsi were so tall. Vansina (2001) estimated that the results obtained by Desmarais are valid despite the inadequacy of the samples. As far as I am concerned, assuming that that practice was genuine, it would not be a mistake to say that the tallness attributed to Tutsi is not racial but the result of social practice. Vansina (2001), however, was less consistent as he evoked Tutsi, Twa and Hutu identities. In validating Desmarais' assertion, he argued that there was no doubt that in the 20th century Rwandans were composed of three populations-implicitly Hutu, Tutsi and Twa-biologically different. He accepted, on the other hand, a social mobility following the rinderpest occurred at the end of the nineteenth century. Moreover, one should consider a survey conducted by Leurquin (1960). He acknowledged that Hutu also had livestock. Lainé (1998) draws attention to the changes in Hiernaux's position between 1950 and 1968 in relation to a relationship between the genetic traits and the racial classifications of the Great Lakes peoples. In a collective article in 1953, it was accepted by Hiernaux that the distribution of the blood characters was in full agreement with the anthropometric data. In his commentary, Lainé (1998) evokes a major epistemological turn in 1956. For Hiernaux, she notes, the similarity of physical characteristics is not sufficient evidence of a close consanguinity, exclusive of an independent biological history. It is now genetics that calls into question typological anthropometry. 


\section{CONCLUSION}

In this work, the definition issues of the concepts related to social cleavages, especially in Africa were discussed. This questioning made it possible to approach the definitions of those concepts in order to set them against the realities of the situation. This approach has led to a rich debate among specialists around those concepts. Thus authors such as Dozon or Vansina suggested that "ethnic group / tribe" in Africa have been introduced by the colonial system and that others like Schilder and Van Binsberger believed that ethnicity dates back from the pre-colonial era. Moreover, it has become clear that those definitions have problems with Rwandan society, as the experts have failed to adopt once and for all a concept to identify Hutu, Tutsi and Twa. Thus, in 1939, Lacger used the concept of "race" and "social class" to identify them in the same work, while Maquet adopted the concept of "caste" in 1952 before preferring that of "social class" in 1964.

Those definitions are therefore less relevant to the study of African societies, in general, and Rwandan society in particular. I believe that this lack of relevance is the result of the application of concepts inspired by racial ideology to ill-known societies. To remedy this, experts should first study the societies of the interior in order to apply to them concepts well suited to varied situations. While the society studied had to be theoretically reshaped to accommodate the definitions of the usual concepts, I would like to propose a different approach, one that would be based on field surveys before defining those societies while taking into account the dynamics of the latter. This proposal would feed into an adequate research problem.

\section{References}

AMSELLE, J.-L. (1985). Ethnies et espaces : pour une anthropologie topologique. In : AMSELlE, J.-L., M'BOKOLO, E. (eds.). Au cœur de l'ethnie. Ethnies, tribalisme et état en Afrique. Paris : La Découverte, p.11-48

BALANDIER, G. (1965). Problématique des classes sociales en Afrique noire. Cahiers internationaux de sociologie. 38. p.1311-1342.

BANTON, M. (1967). Race relations. New York : Basic Books

BAZIN, J. (1985). A chacun son Bambara. In : AMSELLE, J.- L. M'BOKOLO, E, (eds)

Au cœur de l'ethnie. Ethnies, tribalisme et état en Afrique. Paris : La Découverte. p.87127.

BINET, J. (1961). Naissance des classes sociales en Afrique. Revue de l'Action Populaire. 151. p. 956-964. 
BOILLEY, P. (2003). Frontières, ethnies. Les explications faciles des conflits en Afrique ». Après-demain. 452-453. p.11-12.

BOUGLE, C. (1969). Essais sur le régime des castes. Paris : Presses Universitaires de France,

CHRETIEN, J.-P. (1983). Dimension historique de l'ethnicité en Afrique. In : CHRETIEN,J.-P. , PRUNIER, G. (eds) Les ethnies ont une histoire. Paris : Karthala,ACCT, p.5-14.

DE HEUSCH,L.(1968). Le Rwanda et la civilisation interlacustre. Université Libre de Bruxelles: Institut de Sociologie.

DELACAMPAGNE, C. (1983). L'invention du racisme : Antiquité et Moyen âge. Paris: Fayard.

DE LACGER, L. (1939). Ruanda I Le Ruanda ancien II Le Ruanda moderne, Namur: Grands Lacs.

DELMAS, L. (1950). Généalogies de la noblesse (les Batutsi) du Ruanda. Kabgayi : Vicariat Apostolique.

D'HERTEFELT, M. (1962). Le Rwanda. In : D'HERTEFELT, M., TROUWBORRST A.A, SCHERER J.H. Les anciens royaumes de la zone interlacustre méridionale. Rwanda, Burundi, Buha. Tervuren : Musé Royal d'Afrique Centrale.

D’ HERTEFELT, M. (1971). Les clans du Rwanda ancien. Eléments d'Ethnosociologie et d'Ethno-histoire. Tervuren: Musé Royal d'Afrique Centrale.

DOZON, J.-P. (1985). Les Bété : une création coloniale. In : AMSELLE,J-L., M'BOKOLO,E. Au cœur de l'ethnie. Ethnies, tribalisme et état en Afrique. Paris : La Découverte, p.49-85.

DUCROS, A. (1992). La notion de race en anthropologie physique : évolution et conservatisme. Mots. 33. p.121-141.

FARDON, R. (1996). "Destins croisés »: histoire des identités ethniques et nationales en Afrique de l'Ouest. Politique africaine, 61, p.75-97.

FREDRICKON, G. (2003). Racisme, une histoire. Paris : Liana Lévi.

GUILLEMIN, C. (2002). L'idéologie raciste: genèse et langage actuel. Paris: Gallimard 
HIERNAUX, J. (1954). Les caractères physiques des populations du Ruanda et de 1’Urundi. Bruxelles : Institut Royal des Sciences naturelles de Belgique.

KAGAME, A. (1969). Introduction aux grands genres lyriques de l'ancien Rwanda. Butare : Université nationale du Rwanda.

KAGAME, A. (1972). Un Abrégé de l'ethno-histoire du Rwanda. Butare: Université Nationale du Rwanda.

LAINE, A., (1998). Génétique des Populations et Histoire du Peuplement de l'Afrique. Essai d'historiographie et d'épistémologie. Thèse de doctorat. Paris : Université Paris 1 Panthéon-Sorbonne.

LAINE, A. (1999). L'anthropologie génétique et la question de la citoyenneté dans la région des Grands Lacs (Rwanda-Burundi). Droit et Cultures. 38 (2). p.80-106.

LONSDALE, J.(1996). Ethnicité, morale et tribalisme politique. Politique africaine. 61. p.98-119.

MAQUET, J.-J. (1952). Le problème de la domination Tutsi. Zaïre. VI (10). p.10111016

MAQUET, J.-J.(1954). Le système des relations sociales dans le Ruanda ancien. Tervuren. Musé Royal d'Afrique Centrale.

MAQUET, J.-J. (1964). La participation de la classe paysanne au mouvement d'indépendance du Rwanda. Cahier d'Etudes Africaines 4 (16). p.552-568.

M'BOKOLO, E. (1985). Le séparatisme katangais. In : AMSELLE, J.-L. et M'BOKOLO, E., (éd.), Au cœur de l'ethnie. Ethnies, tribalisme et état en Afrique. Paris : La Découverte, p.185-226.

MEMMI, A. (1994. Le Racisme. Description, définitions, traitement, Paris: Gallimard MOUSNIER, R. (1969). Les hiérarchies sociales. De 1450 à nos jours, Paris : Presses Universitaires de France.

NYAGAHENE, A. (1997). Histoire et Peuplement. Ethnies, clans et lignages dans le Rwanda ancien et contemporain. Thèse de doctorat. Paris : Université Paris 7-Denis Diderot.

PAGES, A. (1933). Au Ruanda. Sur les bords du lac Kivu, Congo belge. Un royaume hamite au centre de l'Afrique. Bruxelles : Institut Royal Colonial Belge. 
POUTIGNAT, P. et STREIFF-FENART, J. (2008). Théories de l'ethnicité suivie de BARTH, F. Les groupes ethniques et leurs frontières (trad.), Paris : Presses Universitaires de France.

SELIGMAN, C.G. (1966). Races of Africa. London, New York, Toronto : Oxford University Press.

SIMAR, T.(2003). Etude critique sur la formation de la doctrine des races au XVIIIe siècle et son expansion au XIXe siècle, Genève: Slatkine Reprints.

VANSINA, J. (1962). L'évolution du royaume rwanda dès origines à 1900. Bruxelles : Académie Royale des Sciences d'Outre-mer.

VANSINA, J. (2001). Le Rwanda ancien. Le royaume nyiginya, Paris: Karthala

VIDAL, C. (1985). Situations ethniques au Rwanda. In : AMSELLE, J.-L. et M'BOKOLO, E. Au cœur de l'ethnie. Ethnies, tribalisme et état en Afrique. Paris. p.167-184.

WALLERSTEIN, I. (1960). Ethnicity and national integration in West Africa». Cahier d'Etudes Africaines, 3. p.129-139.

WEBER, M.,(1995). Economie et Société, 2, L'organisation et la puissance de la société dans leur rapport avec l'économie, Paris : Plon. 